\title{
Energy balance in a passive solar building. An attempt at economic assessment
}

\author{
Wiktoria Sobczyk ${ }^{1, a}$ and Katarzyna Sapa ${ }^{2}$ \\ ${ }^{1}$ Ph.D. Eng., Professor AGH, Faculty of Mining \& Geoengineering, AGH University of Science \& Technology, Al. Mickiewicza 30, 30-059 \\ Krakow, Poland \\ ${ }^{2}$ MSc. Eng., Construction and Design Services Andrzej Bracha, ul. Wschodnia 13/14, 28-200 Staszów, Poland
}

\begin{abstract}
The paper emphasizes possibilities for substantially reducing energy consumption with modern ecofriendly buildings. Passive building construction is a sector of the construction industry that has extremely low demand for the energy for heating house interiors. A passive house requires a small amount of energy to provide thermal comfort, but it requires proper systems (HRU, heat pumps, solar collectors) to accomplish that effect. The modification proposal presented in the paper has dramatically reduced the demand for heat capacity of the building. Unfortunately the passive standard has not been reached, but thermomodernisation would allow for a significant reduction of heating costs. The demand per $1 \mathrm{~m} 2$ of heated surface area in a traditional building was 41.9 $\mathrm{W} / \mathrm{m} 2$, while after the modification - only $15.01 \mathrm{~W} / \mathrm{m} 2$. The tested building, if located in a warmer climate, with an average outside temperature of $\geq-10^{\circ} \mathrm{C}$ would certainly perform its function. The use of modern technology ensures high energy savings. Such solutions, however, are not the cheapest on the market, and therefore are less available. The construction of a passive solar buildings is a "green" investment with tangible environmental results. By ensuring the thermomodernisation of a traditional building we can enjoy real environmental and economic benefits.
\end{abstract}

\section{Solar energy conversion methods}

Solar energy is an energy source specifically for use by beings living on Earth. The sun produces vast amounts of energy in a form of radiation. Only a small portion of this radiation reaches Earth, yet it is still 15 times more than is demanded. This source has one disadvantage though - it produces low-density energy which makes its conversion problematic [1].

The intensity of solar radiation varies across different regions. Poland has been divided into 11 sun power regions based on their usability for solar energy production. Radiation is the sum of the total radiation exposure and the greatest number of hours of sunshine. The best conditions in this respect can be found in the coastal region (northern Poland) and Podlasie-Lublin region (eastern Poland). The least favourable solar conditions can be found in the regions of Upper and Lower Silesia - this is due to the local severity of anthropogenic air pollution (Fig. 1).

The total radiation per year in Poland is $3600 \mathrm{MJ} / \mathrm{m}^{2}$ $( \pm 10 \%)$. Utilisation of radiation energy is effective only for 6 months: from April to September (when 80\% of the annual solar insulation is observed). This is caused by the absence of technologies to store solar energy [2]. There are many ways of making use of solar energy reaching the Earth surface. However, three basic methods of solar energy conversion are practicable: a. thermal energy - photothermal conversion b. electrical energy - photovoltaic conversion c. energy related to chemical processes - photochemical conversion.

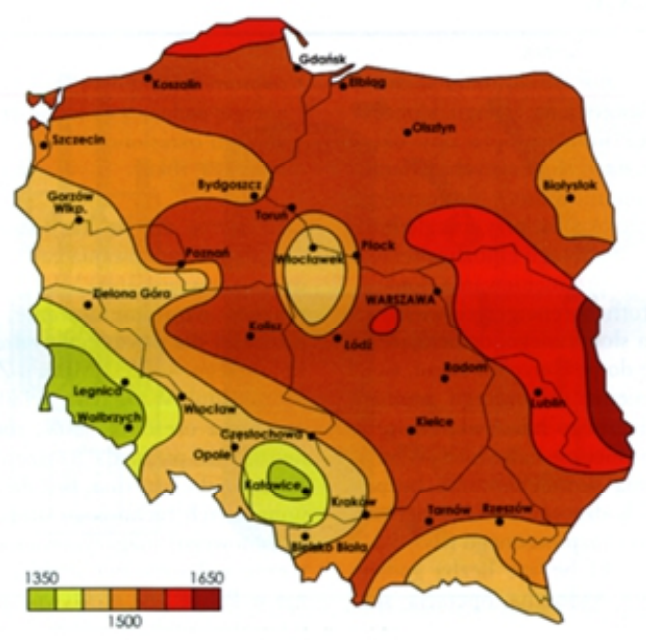

Figure 1. Number of hours of yearly solar insolation for Poland (Wnuk 2007)

\section{Thermal energy - photothermal conversion}

Production of hot water is the simplest, most available and efficient method of using solar energy. Efficiency

\footnotetext{
a Corresponding author: sobczyk@agh.edu.pl
} 
of energy conversion in solar collectors designed to convert solar energy into thermal energy may amount to as much as $90 \%$, while the structure and operation of such devices are relatively uncomplicated. With all these factors taken into account, favourable climate conditions are still required; therefore the expected results will not be achieved everywhere. Solar collectors enable photothermal conversion of solar radiation in order to heat spaces and tap water, to produce electrical energy and to conduct chemical processes. Solar collectors require a carrier to transport and transfer heat. The temperature of the working substance at the device outlet determines the design of the collector, which can be of low-, medium- and high-temperature type. Collectors can also be classified based on the type of working substance, namely liquid and vacuum. The basic element of a collector is the absorber, i.e. a plate coated with a thin layer of black nickel, copper and other material.

The absorber boasts a high coefficient of solar radiation absorption and low coefficient of thermal radiation emission. The flow-through part of the collector is insulated with a material that has a low thermal conductivity coefficient (mineral wool, polyurethane foam). Transparent covers - such as glass panes or transparent insulation - are used for sealing the surface of the collector. Such elements minimize heat loss from the surface of the absorber by convection.

\section{Electrical energy - photovoltaic conversion}

The most convenient way to obtain energy is, undeniably, generating it in an electrical form. There are also methods of obtaining electricity from the energy carried by solar radiation - e.g. photovoltaics produce direct current that is usually converted into alternating current. However, it is only profitable to build and install the required devices in highly-insolated areas, where the sun shines for 1800-2000 hours per year on average.

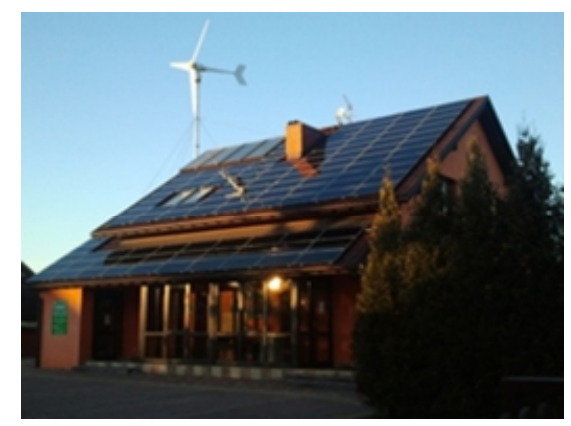

Figure 2. Use of alternative sources of energy: photovolta ic cells and $0.5 \mathrm{~kW}$ household wind turbine. "EKOMOTEL na Wierzynka”. Wieliczka near Krakow (photo by Ł. Steg)

A photovoltaic cell is a semiconductor which converts solar energy into electricity. A typical photovoltaic cell is a plate made of crystalline or polycrystalline silicon where a barrier for electric potential is formed. The sunlight that reaches a photovoltaic cell generates pairs of electric energy mediums (electrons and positive holes). Under the influence of the electric field, they are scattered, resulting in a potential difference, i.e. PV voltage. When a connection with the receiver of electricity is made, the flow of electric current commences. The thickness of the plates is in the range of 200-400 micrometres. A single cell produces 1-2 watts of power. To provide higher voltages or currents photovoltaic cells are connected in series or parallel forming photovoltaic modules (Figure 2).

Passive solar systems can use some elements of the building (e.g. glazing) to accumulate heat. No intermediate medium is used for heat transport and transfer. Sun rays in the form of visible and infra-red waves which penetrate into the rooms, being accumulated in walls, floors and ceilings. The elements heat up and emit thermal radiation, producing the greenhouse effect [3].

Passive heating methods are effective only for buildings with a low unit energy demand for heating purposes. They may also be an auxiliary source of heat in conventional buildings. Energy related to chemical processes - photochemical conversion

This type of solar energy conversion is mainly used in agriculture (photosynthesis). Solar energy is transformed into usable energy by recuperation of the energy from organic matter by way of combustion or through other decomposition process. Approximately 3\% of solar energy can be extracted, but the process itself is complicated and costly.

\section{Energy-efficient building and passive building - definitions}

Energy-efficient buildings (EeB) use intelligent technologies which allow for high heat comfort and low energy consumption. In this way, operating costs decrease. The basis for any EeB is maintaining air tightness. Building materials play a crucial role, such as insulating materials and heat absorbing windows. EeBs have low energy consumption: $\mathrm{E}<60 \mathrm{kWh} / \mathrm{m}^{2}$ per year.

The main advantage of an EeB is not losing heat through outside walls. This kind of building uses the heat produced by a variety of home appliances and utilises natural light as well as the ventilation system for re-use of the heat contained in the air which is removed to the outside. An EeB must meet certain conditions:

- Its location should take into account land relief, sunshine and wind directions;

- It should have a compact design and small windows on the north side;

- It should be equipped with a layer of thermally insulating material;

- Windows and doors should be very tight and well insulated thermally;

- Ventilation should be automatically controlled and feature a heat recovery solution.

A very important design requirement for passive houses is the choice of a suitable building site, providing passive solar heat gains. The correct orientation of the house versus cardinal points allows for optimum use of the properties of glazing (absorption of sunlight). Installing the largest number of windows facing south and west brings greatest benefits [4].

In the case of EeBs, just as with passive housing, modern technologies are used to reduce energy 
consumption. The most frequent are solar collectors, heat pumps and heat recovery units (HRU).

\section{Materials and methods}

Research and analyses were carried out based on analysing reports and regulatory documents (EU directives, Polish legislation, strategies, strategic documents of the Ministry of Economy and the Ministry of Environment in Poland).

The following scientific methods were used in the study: modelling and design method, analytical method (calculation method). Heat balance was calculated using Herz OZC, version 3.0 C computer software 1994-2007 P.W.

\section{Modelling architectural solutions for passive buildings}

Architectural and construction design combines many essential components and solutions necessary for solar energy utilisation: "solar" roof, materials used (passive doors and windows, tight connections, proper insulation), passive systems, extended glazing on south-eastern façades, adequate layout of rooms, as well as geometry and orientation of the building. Unfortunately, even today, in times of energy crisis, not everyone considers using cheap solar energy worthwhile (Figure 3).
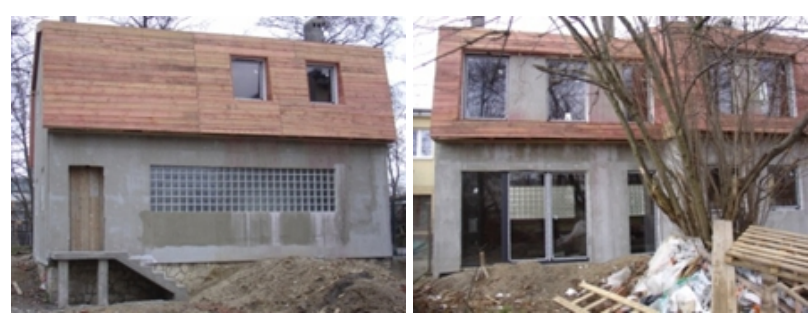

Figure 3. Improperly designed new building. a. south-western façade without glazing, b. northern façade - fully glazed,

Kraków, Zarzecze street (photo by: W. Sobczyk)

In passive houses hoods are often used to control solar radiation reaching rooms. In the summer, hoods prevent radiation from getting in, while in the winter, when the position of the sun is lower, the rays easily reach rooms. This leads to a reduction in energy consumption by $7 \%$ in traditional buildings, while in passive buildings - by up to $30 \%$. The thermal balance can be improved by installing glass porches accumulating heat, shutters or energy-saving roller shutters.

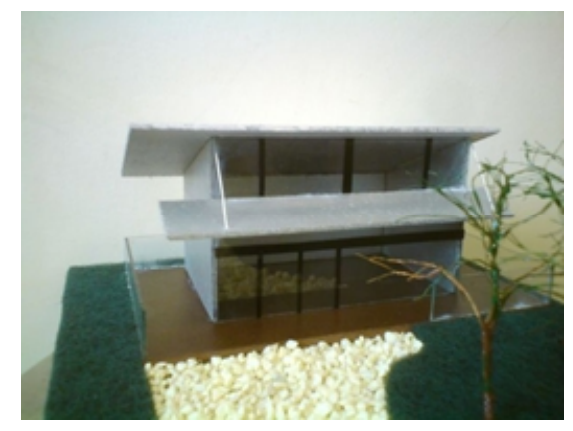

Figure 4. Model of a passive building (by K. Figiel)

The shape of the building should be simple, compact and limiting heat loss through outside walls (Figure 4).
Recesses of end walls increase interior sun exposure, so this kind of reinforcement is advantageous when designing passive buildings.

An important element is the layout of rooms. Spaces which require the lowest temperature of all the rooms (staircases, utility rooms) should be facing north, while bathrooms should be located in the middle of the building. Spaces which require intensive lighting should be facing south [5].

Moreover, the proper design of greenery surrounding the building is a very helpful element. The southern façade of the building decorated with deciduous trees increases the efficiency of the energy balance. In the summer, sunlight is partially blocked by tree leaves, thus protecting the building from overheating, while in the winter trees drop their leaves and allow a sufficient amount of energy to reach the building. On the north, coniferous trees should be planted that would protect the building from cold winds.

\subsection{Design of a passive building}

Buildings that were put on the real estate market after 2009 are required to have an energy certificate that determines their energy efficiency. The basis for quality control is the air-tightness test mentioned above and thermal images.

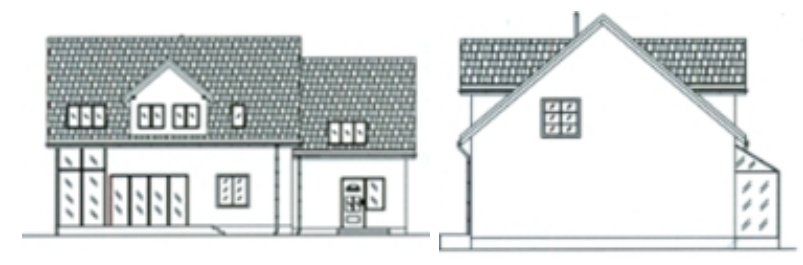

Figure 5. Southern façade (a) and western façade (b) of the designed building (dev. by the authors)

\subsubsection{Design of the solar system}

The solar system comprises the Viessmann flat plate collector which ensures high operating efficiency at an affordable price of investment (Fig. 6). The exceptionally high operating efficiency, safety of operation and durability are confirmed by quality tests compliant with the European and Polish standard PN-EN 12975 and Solar Keymark Certificate (www.viessmann.pl). The surface area of Vitosol $200-\mathrm{F}$ collector is $2.3 \mathrm{~m}^{2}$, and the device itself is easily installable. This particular collector was selected as it can cooperate with compact devices, such as condensation boiler Vitodens 343-F and heat pump Vitocal 343-G.

The heat transfer coefficient $U$ in traditional buildings is $0.242 \mathrm{~W} /\left(\mathrm{m}^{2} \cdot \mathrm{K}\right)$. In our modified design, a $16 \mathrm{~cm}$-thick mineral wool insert was replaced with $20 \mathrm{~cm}$-thick ECOTHERM plates whose heat transfer coefficient $\lambda$ is $0.023 \mathrm{~W} / \mathrm{m} \cdot \mathrm{K}$. This offers $70 \%$ better insulation than in the case of ordinary insulating materials.

The design incorporated, internal walls in the garage and service/utility room insulated with ECOTHERM wall plates which had been previously insulated with vapourpermeable membrane. 


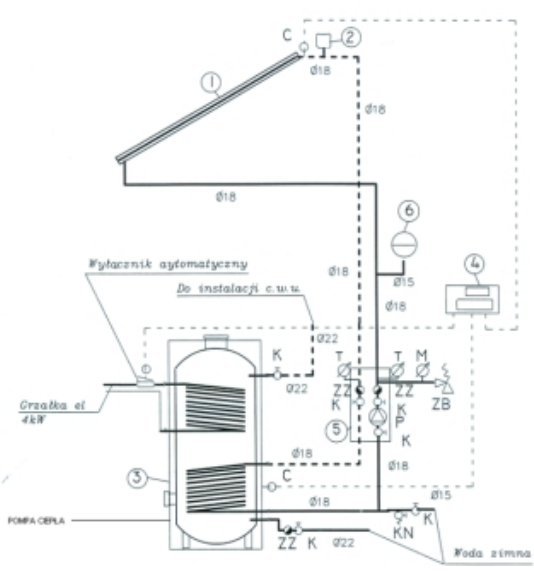

Figure 6. Diagram of the solar system (dev. by the authors) 1 . Flat plate collector $2 \times 2.32 ; 2$. Vent; 3 . Tray V=3001; 4 . Differential controller; 5. Pump group; 6. Diaphragm pressure expansion vessel V=121; P. Circulation pump; K. Nozzle; ZZ. Return valve; $Z B$. Safety valve; C. Temperature sensor; T. Thermometer; M. Manometer; KN. Tap with a hose nipple.

We also applied the passive effect by adding a small glazed porch to the southern façade to accumulate heat (Figure $5 b$ ). This structure is one of the methods of retaining heat energy and gradually transferring it to the building interior. A part of the wall opposite the windows in the living room will be covered with a heat accumulating material (clinker) [6].

\subsubsection{Installation of the HRU}

To ensure trouble-free and economical operation, we decided to install the AERIS 350 LUXE VV HRU (Figure 7). It is a top-class counterflow heat exchanger, which offer a 95\% efficiency. The built-in filters guarantee clean air, while the polypropylene insulation inside the machine ensures silent operation. By installing an auxiliary heater, the supply air temperature can be controlled. Another advantage of the AERIS HRU is the possibility to connect the controller to the rapid ventilation in the bathroom, kitchen and toilet. The HRU can be programmed according to weekly or hourly options/modes. It can cooperate with the ARTIC cooling system [7]. Before the HRU can be installed, the route of the main cable should be determined, the volume of air should be correctly calculated, the diameter and insulation of ducts should be carefully selected, while the pressure should be equalized. An important element is to ensure an adequate level of humidity in the rooms, especially during the heating season. Moisture and $\mathrm{CO}_{2}$ sensors that can be connected to the HRU are well worth investing in. In addition to that, all components of the system should be carefully selected: ducts, diffusers, silencers, etc. The HRU must have a low power heater to support heat recovery in the periods when the outside air is very cold.

The design also takes the distribution of air supply and exhaust devices into consideration. The former will be installed in least polluted spaces, i.e. bedrooms, living rooms and guest rooms, while the latter - in the kitchen, bathrooms, hall, garage, i.e. spaces where air can be contaminated or too humid. The air flow rate should not exceed $0.2 \mathrm{~m} / \mathrm{s}$. The air supply devices should be spaced away from the places of human occupancy (e.g. over beds, armchairs or desks) and their number should match the cubic volume and throughput of the spaces.
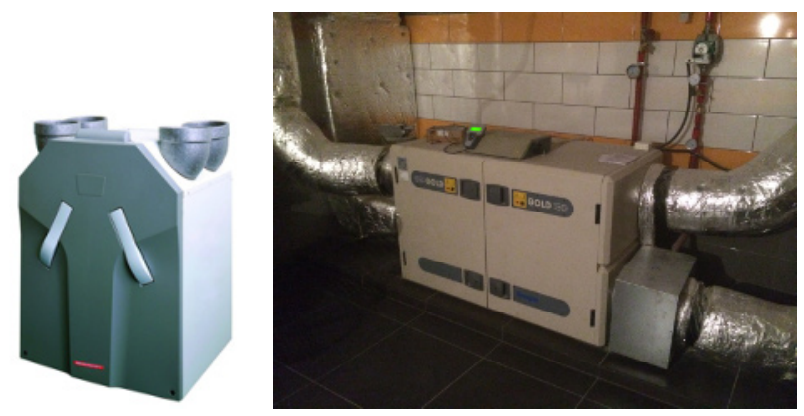

Figure 7. Model of the AERIS 350 LUXE VV recuperator and the same HRU installed in a house (photo by: M. Jarząbek)

Condensation of the water vapour contained in the cooled air takes place in the exchanger; it is then directed to the vents, and then discharged into drains.

\subsubsection{Domestic hot water (DHW)}

The DHW system is the primary heating system in passive building construction. Heating of rooms takes places simultaneously with the preparation of DHW and is linked to it. The heating system integrated with solar collectors and a heat pump with a ground heat exchanger is a source of hot water. The heat pump will be used for heating the spaces equipped in underfloor heating solutions. In the summer, the solar collector will meet the heat demand required for preparation of DHW. In the winter, the collectors will be supported by the heat pump and an energy-efficient electric heater. In the periods of increased cloudiness in the summer, it is assumed that an electric heater will be used just like in the winter.

In the designed building we have planned to install the Vitocal 343-G heat pump. Its bottom source of heat is a horizontal ground heat exchanger. It is a high capacity, energy-efficient electronic pump of the brine-towater type, powered with direct current. It has the userfriendly Vitotronic controller and is capable of quiet operation [8]. The heat pump is integrated with floor heating in rooms while it supports the HDW heating system (in the summer it is mainly supplied by the solar collector).

\section{Results}

A standard for passive houses is achieving a coefficient of heat transfer through the building envelope $\leq 0.15 \mathrm{~W} / \mathrm{m}^{2} \cdot \mathrm{K}$. In addition to that, the demand for energy for heating should be $\leq 15 \mathrm{kWh} / \mathrm{m}^{2}$ year, and the maximum power demand for heating $\leq 10 \mathrm{~W} / \mathrm{m}^{2}$. In the calculations we have taken material parameters into consideration in order that a low heat transfer coefficient could be achieved. Data was entered into the software to calculate the energy balance of the building. Having introduced designated construction and insulating materials, we obtained the required building envelope coefficients so that an airtight layer could be obtained. The partitions which ensure creating such a layer have the coefficients as shown in Table 1. 
Table 1. Coefficients of heat transfer through the building envelope in passive and traditional buildings (dev. by the authors)

\begin{tabular}{|l|c|c|c|}
\hline Symbol & $\begin{array}{c}\text { Description of } \\
\text { the building } \\
\text { envelope }\end{array}$ & $\begin{array}{c}\text { Passive } \\
\text { building } \\
\mathbf{U}\left[\mathbf{W} / \mathbf{m}^{2} \cdot \mathbf{K}\right]\end{array}$ & $\begin{array}{c}\text { Traditional } \\
\text { building } \\
\mathbf{U}\left[\mathbf{W} / \mathbf{m}^{2} \cdot \mathbf{K}\right]\end{array}$ \\
\hline DZ & external door & 0.8 & 2.0 \\
\hline O & window & 0.7 & 1.5 \\
\hline OD & roof window & 0.7 & 1.5 \\
\hline PD1 & floor 1st zone & 0.069 & $\begin{array}{c}0.294 \\
\text { (parquet) } \\
0.451 \\
\text { (terracotta) }\end{array}$ \\
\hline PD2 & floor 2nd zone & 0.069 & $\begin{array}{c}0.418 \\
\text { (parquet) } \\
\text { (terracotta) }\end{array}$ \\
\hline SZ & external wall & 0.137 & \\
\hline SZO & $\begin{array}{c}\text { insulated } \\
\text { external wall }\end{array}$ & 0.088 & \\
\hline DB & balcony door & & 1.5 \\
\hline P & external wall & & 0.506 \\
\hline D & roof & & 0.242 \\
\hline
\end{tabular}

where: U - heat transfer coefficient

\subsection{Calculation of the energy balance}

According to the calculations, it was possible to achieve the effect of an airtight building envelope, particular attention was paid to minimizing thermal bridges. A different situation occurred with the maximum demand for heat, which should be no more than $10 \mathrm{~W} / \mathrm{m}^{2}$. According to software calculations, this value equals as much as $27.3 \mathrm{~W} / \mathrm{m}^{2}$ (symbol $\mathrm{Q}_{\mathrm{f}}$ ). However, this amount was calculated without taking into account the recuperation of heat from ventilation (as much as $70.9 \%$ ). With the efficiency of the HRU we have selected, the coefficient is calculated according to the formula:

$$
Q_{c}=Q_{o^{-}}\left(Q_{\text {vent. }} \times 0.95\right)[W]
$$

where:

$Q_{c}$ - designed demand for heat capacity

$Q_{o}$ - designed demand for heat capacity incl. heat loss through ventilation (designed demand for heat capacity: $\mathrm{Q}_{0}=6244 \mathrm{~W}$ )

$Q_{\text {vent. - demand for heat for ventilation (designer }}$ Formula: demand for heat capacity $\mathrm{Q}_{\text {vent. }}=2954 \mathrm{~W}$ ).

$$
\begin{gathered}
6244 W-(2954 W \cdot \times 0.95)=6244 W-2806.3 \\
W=3437.7 W \\
3437.7 W: 229 m^{2}=15.01 \mathrm{~W} / \mathrm{m}^{2}
\end{gathered}
$$

Demand for capacity per $1 \mathrm{~m}^{2}$ of heated surface area is $15.01 \mathrm{~W}$.

\section{Discussion}

The result of $15.01 \mathrm{~W} / \mathrm{m}^{2}$ resulting from the calculation of demand per $1 \mathrm{~m}^{2}$ of heated surface area is satisfactory due to the value characteristic of this traditional building, namely $41.9 \mathrm{~W} / \mathrm{m}^{2}$. However, it still fails to meet

\begin{tabular}{|c|c|c|}
\hline & $\begin{array}{c}\text { Traditiona } \\
\text { residential } \\
\text { building }\end{array}$ & $\begin{array}{c}\text { Passive } \\
\text { residential } \\
\text { building }\end{array}$ \\
\hline \multicolumn{3}{|c|}{ Location: Oględów } \\
\hline \multicolumn{3}{|c|}{ Designer: Sapa Katarzyna, M.Sc. Eng. } \\
\hline \multicolumn{3}{|c|}{ Date of calculation: 6 January $2015,5: 08 \mathrm{pm}$} \\
\hline \multicolumn{3}{|c|}{ Locality: Oględów } \\
\hline \multicolumn{3}{|c|}{$\begin{array}{c}\text { Climate zone: } 3 \\
\text { Outdoor temp. }\left[{ }^{\circ} \mathrm{C}\right]:-20\end{array}$} \\
\hline \multicolumn{3}{|c|}{$\begin{array}{l}\text { Heated surface area }\left[\mathrm{m}^{2}\right]: 229 \\
\text { Heated cubic volume }\left[\mathrm{m}^{3}\right]: 540\end{array}$} \\
\hline $\begin{array}{l}\text { Designed demand for } \\
\text { heat capacity Qo [W\} }\end{array}$ & 9581 & 6244 \\
\hline $\begin{array}{l}\text { Demand for heat } \\
\text { capacity for ventilation } \\
\text { Qvent }[\mathrm{W}]\end{array}$ & 2954 & 2954 \\
\hline $\begin{array}{l}\text { Additional heat gains } \\
\text { in rooms } \text { Qzc [W] }\end{array}$ & $\mathbf{0}$ & $\mathbf{0}$ \\
\hline $\begin{array}{c}\text { Demand per } \mathrm{m}^{2} \text { of } \\
\text { heated surface area Qf } \\
{\left[\mathrm{W} / \mathrm{m}^{2}\right]}\end{array}$ & 41.9 & 27.3 \\
\hline $\begin{array}{c}\text { Demand per } \mathrm{m}^{3} \text { of } \\
\text { heated cubic volume } \\
\mathrm{Qv}\left[\mathrm{W} / \mathrm{m}^{3}\right]\end{array}$ & 17.7 & 11.6 \\
\hline $\begin{array}{l}\text { Annual demand for } \\
\text { heat for heating } \\
\text { purposes Qh [GJ/year] }\end{array}$ & 87.10 & 65.17 \\
\hline $\mathrm{Qh}[\mathrm{kWh} /$ year] & 24195 & 18103 \\
\hline $\begin{array}{c}\text { Coefficient of seasonal } \\
\text { demand for heat EA } \\
{\left[\mathrm{MJ} / \mathrm{m}^{2} \text {.year }\right]}\end{array}$ & 381.0 & 285.1 \\
\hline $\begin{array}{c}\text { EA }\left[\mathrm{kWh} / \mathrm{m}^{2} \cdot \times \text { year }\right]: \\
105.8\end{array}$ & 105.8 & 79.2 \\
\hline $\begin{array}{l}\text { Coefficient of seasonal } \\
\text { demand for heat EV } \\
{\left[\mathrm{MJ} / \mathrm{m}^{3} \times \text { year }\right]: 161.3}\end{array}$ & 161.3 & 120.7 \\
\hline $\begin{array}{c}\mathrm{EV}\left[\mathrm{kWh} / \mathrm{m}^{3} \cdot \times \text { year }\right]: \\
44.8\end{array}$ & 44.8 & 33.5 \\
\hline & & $\begin{array}{c}\text { Herz OZC } \\
\text { version 3.0 (c) } \\
\text { 1994-2007 P.W. }\end{array}$ \\
\hline
\end{tabular}
the standard of passive building: $\leq 10 \mathrm{~W} / \mathrm{m}^{2}$.
Table 2. Comparison of energy balance of a traditional and passive building (dev. by the authors)

The coefficient of seasonal demand for heat (in $\mathrm{kWh} / \mathrm{m}^{2} \cdot$ year) it also too high:

$\left(15.01 \mathrm{~W} / \mathrm{m}^{2} \times 1000\right): 365$ days $=41 \mathrm{kWh} / \mathrm{m}^{2} \cdot \times$ year.

This result takes into account heat recovery from ventilation enabled by the installed HRU.

The designed heat load of a traditional building $\mathrm{Q}_{\mathrm{c}}$ is $9581 \mathrm{~W}$, so the coefficient of seasonal demand for heat $\mathrm{E}_{\mathrm{A}}$ is $114.6 \mathrm{kWh} / \mathrm{m}^{2} \cdot \times$ year: $9581 \mathrm{~W}: 229 \mathrm{~m}^{2}=41.8 \mathrm{~W} / \mathrm{m}^{2}$

$\left(41.8 \mathrm{~W} / \mathrm{m}^{2} \times 1000\right): 365$ days $=114.6 \mathrm{kWh} / \mathrm{m}^{2} \cdot \times \cdot$ year.

This result meets the requirements of the Polish Standard, under which the coefficient for buildings should be $\mathrm{EA}=120 \div 180 \mathrm{kWh} / \mathrm{m}^{2} \cdot \times$ year.

The energy balance of the passive building is as follows:

- transmission heat loss + ventilation heat loss $=$ heat loss

- $\quad$ heat gain from solar energy + gains from internal heat sources $=$ free heat

- $\quad$ free heat - ability to use $=$ heat gains

- heat loss - heat gains = heat demand 
The demand for primary energy comprises of meeting all of the energy needs required by the house (heating, HDW preparation, ventilation, air conditioning, lighting, cooking). Energy-efficient appliances (dishwashers, washing machines, dryers) are therefore also required to reduce demand to a minimum [9].

Table 3. Demand for electricity and primary energy for basic household chores [10]

\begin{tabular}{|c|c|c|}
\hline \multirow{2}{*}{ De mand } & $\begin{array}{c}\text { Demand for } \\
\text { primary energy }\end{array}$ & $\begin{array}{c}\text { Demand for } \\
\text { electricity }\end{array}$ \\
\cline { 2 - 3 } & $\mathrm{kWh} /$ year & $\mathrm{kWh} /$ year \\
\hline dishwasher & 475 & 160 \\
\hline dishwasher - hot water & 288 & 103 \\
\hline washing machine & 307 & 621 \\
\hline $\begin{array}{c}\text { washing machine - hot } \\
\text { water }\end{array}$ & 184 & \\
\hline $\begin{array}{c}\text { clothes dryer with } \\
\text { exhaust ducts } \\
\text { evaporation when } \\
\text { drying }\end{array}$ & 1845 & 416 \\
\hline $\begin{array}{c}\text { cooling / freezing } \\
\text { cooking }\end{array}$ & 1236 & 468 \\
\hline lighting & 1384 & 225 \\
\hline $\begin{array}{c}\text { electronic devices, } \\
\text { appliances }\end{array}$ & 668 & 350 \\
\hline total of auxiliary energy & & 425 \\
\hline Total & 2467 \\
\hline
\end{tabular}

Buildings offered on the real estate market since 2009 must have an energy certificate, specifying the energy consumption of a given structure. The basis for the quality control of passive buildings are infrared images and the aforementioned airtight test. The heat loss in passive buildings is much lower than in traditional buildings, assuring indoor thermal comfort. In traditional buildings more than $50 \%$ of the energy is spent on heating, while in passive buildings only $20 \%$ of energy is required for that purpose.

\section{Environmental education of the society - a chance for environmental protection}

The environmental education of society in the field of utilising alternative solutions in building thermoregulation should therefore be the top priority for state environmental and energy policy. Raising awareness of the benefits of the implementing nonconventional solutions in residential buildings may bring about huge environmental and social gains. Thoughtless discharge of heated air into the atmosphere through building chimneys is a needless wastefulness [11-15].

So far several thousand passive houses have been built in Europe. Inhabitants of these buildings confirm that the costs of energy have significantly dropped, while the comfort indoors remains high. Thermomodernisation undertakings are a great opportunity for environmental protection, development of the labour market and cities in the future.

In terms of energy use, Poland cannot demonstrate required efficiency. This means that the depletion of natural resources, fossil fuels and environmental pollution are gradually weakening the national economy [16-20]. All the buildings in Poland completed in the past years must undergo thermomodernisation and the construction of new passive buildings should commence. The cost of building a passive house is slightly higher than the cost of a traditional building (an increase by $15 \%$ of the investment outlays), however, passive constructions require no financial expenditure for the heating system. Therefore additional costs are compensated for fairly quickly. Furthermore, the construction of a passive house does not require testing new building materials as well-known materials are used, such as are also used in traditional construction. Erecting passive buildings is based on technologies which have already been tried and tested. This means that passive technologies may be utilised in a wide range of applications.

Educating the society about the possibilities offered by the modern construction industry is necessary for passive buildings to become more popular. Investors usually concentrate on standard solutions - cheap and easy to implement, without making the effort to find out what else is available. The designer's task is to present all solutions and to spread knowledge about innovations so that we can enjoy living in healthy, energy-efficient, green houses.

\section{Conclusions and policy implications}

Today's modern construction industry offers increasingly airtight and warm houses and it pays much attention to the selection of materials which will ensure the lowest energy losses. Warm and airtight windows, modern building materials, minimizing the number of thermal bridges and lowering the heat transfer coefficient due to the excellent insulating materials and their proper installation are all elements significantly affecting the energy demand of a building. Since 2009 all new buildings need to obtain certificates to determine their energy efficiency.

Passive building construction is a sector of the construction industry that has extremely low demand for the energy for heating house interiors. A passive house requires a small amount of energy to provide thermal comfort, but it requires proper systems (HRU, heat pumps, solar collectors) to accomplish that effect.

Modification of a traditional building into a passive building is quite expensive and requires a large amount of work (capital-intensive investment). It is much easier to build a passive house from scratch, which reduces costs and allows for much greater freedom in terms of design. In both cases, subsidies can be obtained for installations that use alternative energy sources.

The modification proposal presented in the paper has dramatically reduced the demand for heat capacity of the 
building. Unfortunately the passive standard has not been reached, but thermomodernisation would allow for a significant reduction of heating costs. The demand per $1 \mathrm{~m}^{2}$ of heated surface area in a traditional building was $41.9 \mathrm{~W} / \mathrm{m}^{2}$, while after the modification - only 15.01 $\mathrm{W} / \mathrm{m}^{2}$. The tested building, if located in a warmer climate, with an average outside temperature of $\geq-10^{\circ} \mathrm{C}$ would certainly perform its function. The use of modern technology ensures high energy savings. Such solutions, however, are not the cheapest on the market, and therefore are less available.

Building a passive solar house is an eco-friendly investment and the resultant environmental effects are tangible. Significant environmental and economic benefits can be obtained through thermomodernisation of a traditional building [1]. Furthermore, passive building construction contributes to lower consumption of fossil fuels, the resources of which are shrinking along with the increasing demand for energy.

In Poland today, the degree of electricity and thermal energy utilisation is very high. The interest in ecofriendly investments has been growing with every year. The supporters of energy-efficient buildings, consuming much less energy than traditional buildings, have also been growing in number.

Protection of the natural environment is a standard component of energy policies of any country in the world. The economic balance demonstrates that the application of solar technologies in the construction industry has got a bright future. The global population is growing which entails rising demand for energy.

Many countries, including Poland, are now faced with an energy crisis. The global resources of fossil fuels will soon be depleted. The situation is further aggravated by the fact that fossil fuel deposits are often located in areas subject to strict protection, such as the Natura 2000 network.

In the light of this, searching for alternative energy sources has become crucial to ensuring energy security. Rational utilisation of solar power solves the issue of increased energy demand. It should be noted that the energy of the sun is not only widely available and inexpensive, but also it does involve noxious gas or dust emissions.

Environmental education of the society in the use of alternative solutions of building thermoregulation is a key to environmental and power policies of the state [21]. Raising awareness among the society of the advantages of applying unconventional solutions in residential buildings may bring great environmental and social gains.

The primary goals of EU climate and energy policy are improving energy efficiency and increasing the share of renewable energy in the total energy balance of the European Union. Poland's energy policy is based on the strategy of balancing the safety of energy materials supply, effectiveness of economic processes and environmental protection.

\section{Acknowledgements}

Paper developed as part of statutory work no. 11.11 .100 .482

\section{References}

1. A. Ostrowska, W. Sobczyk, M. Pawul. Ocena efektów ekonomicznych i ekologicznych wykorzystania energii słonecznej na przykładzie domu jednorodzinnego. Annual Set The Environment Protection 15 (2013)

2. R. Wnuk. Instalacje $w$ domu pasywnym $i$ energooszczędnym. Przewodnik Budowlany (2007)

3. www.passivesolarenergy.info

4. R. Piotrowski, P. Dominiak. Budowa domu pasywnego krok po kroku. Przewodnik Budowlany 12 (2008)

5. K. Ochociński. Budownictwo pasywne. Biuletyn Wielkopolskiej Okręgowej Izby Inżynierów Budownictwa 1, 18 (2008)

6. A. Kaczkowska. Dom pasywny. Wydawnictwo i Handel Książkami „KaBe” Krosno (2009)

7. www.rekuperatory.pl

8. www.viessmann.pl

9. J. Paska. Wytwarzanie rozproszone energii elektrycznej. Oficyna Wydawnicza Politechniki Warszawskiej, Warszawa 2010.

10. W. Feist, U. Münzenberg, J. Thumulla, B. Schulze. Podstawy budownictwa pasywnego. Wyd. Polski Instytut Budownictwa Pasywnego, Gdańsk (2008)

11. A. Malada, W. Sobczyk. Uprawa roślin energetycznych jako forma aktywizacji środowisk wiejskich. Zeszyty Naukowe Katedry Inżynierii Procesowej Uniwersytetu Opolskiego, 2 (2005)

12. W. Sobczyk. Uprawa wierzby energetycznej w województwie małopolskim. W: Problemy współczesnej techniki w aspekcie inżynierii i edukacji. Wyd. Akademii Pedagogicznej (2005)

13. W. Sobczyk. Plonowanie wierzby wiciowej - w świetle badań. Polityka Energetyczna 10, 2 (2007)

14. W. Sobczyk. Wykorzystanie alternatywnych źródeł energii w Zawoi Przysłopie (Małopolska). Folia Scientiarum Universitatis Technicae Resoviensis 252, Budownictwo i inżynieria środowiska, 47 (2008)

15. W. Sobczyk. Evaluation of harvest of energetic basket willow. TEKA Komisji Motoryzacji i Energetyki Rolnictwa PAN XI (2011)

16. B. Klojzy-Karczmarczyk, A. Karczmarczyk. Systemy grzewcze z pompą ciepła jako element realizacji programów ochrony środowiska. Polityka Energetyczna, 3 (2005)

17. B. Klojzy-Karczmarczyk, A. Karczmarczyk. Zanieczyszczone wody podziemne jako niskotemperaturowe źródło ciepła w systemach grzewczych. Polityka Energetyczna 1, 9 (2006)

18. B. Klojzy-Karczmarczyk, A. Karczmarczyk, J. Mazurek. Możliwości wykorzystania wód kopalnianych jako dolnego źródła dla pompy ciepła na przykładzie kopalni Trzebionka. Polityka Energetyczna 9 (2006)

19. T. Olkuski, K. Stala-Szlugaj. Pierwiastki promieniotwórcze w węglu oraz w produktach odpadowych powstających podczas jego spalania. Rocznik Ochrona Srodowiska Annual Set of Environmental Protection 11, 2 (2009) 
20. L. Styszko, D. Fijałkowska, M. Sztyma. Wpływ warunków pozyskania biomasy na odrastanie pędów wierzby energetycznej w czteroletnim cyklu. Rocznik Ochrona Środowiska Annual Set of Environment Protection 12 (2010)

21. W. Sobczyk., A. Kowalska. The techniques of producing energy from biomass. TEKA Commission of Motorization and Energetics in Agiculture PAN, XII (2012) 